\title{
The EU Tax Revisited: Should there be One? And will there be One?
}

\author{
by Steffen Osterloh, Friedrich Heinemann and Philipp Mohl
}

\begin{abstract}
Preceding the upcoming review of the EU Financial Framework, the idea to shift the common financing system from national contributions to an EU tax has been repeatedly voiced. This contribution presents an overview of the arguments raised in favour of and against such a reform, followed by a statistical analysis of its distributive effects on the Member States. The findings indicate that, in addition to the major drawbacks of an EU tax derived from normative analyses, no tax exists which might create a distributional pattern which is at least roughly similar to the existing one. Therefore, given the veto power of national representatives in the Council, the introduction of an EU tax would only be possible if it were accompanied by a reinforced correction mechanism. In sum, an EU tax would not solve the shortcomings of the current fiscal constitution.
\end{abstract}

Mit Blick auf die anstehende Überprüfung der Finanziellen Vorausschau der EU wurde wiederholt der Vorschlag vorgebracht, im Rahmen der Finanzierung der Union von Beiträgen der Mitgliedstaaten zu einer EU-Steuer überzugehen. Dieser Beitrag gibt einen Überblick über die Argumente von Befürwortern wie Gegnern einer solchen Reform. Dem schließt sich eine statistische Analyse der Verteilungswirkungen auf die Mitgliedstaaten an. Daraus lässt sich schließen, dass nicht nur normative Erwägungen gegen eine EUSteuer sprechen, sondern zudem keine mögliche Steuer annähernd ähnliche distributive Effekte auf die Mitgliedstaaten wie das gegenwärtige Finanzierungssystem hätte. Vor dem Hintergrund des Einstimmigkeitserfordernisses im Ministerrat wäre die Einführung einer EU-Steuer somit nur in Verbindung mit einem verstärkten Ausgleichsmechanismus möglich. Im Ergebnis wäre eine EU-Steuer keine Lösung für die Mängel des gegenwärtigen Finanzierungssystems.

\section{Introduction}

Not only since the exhausting negotiations on the Financial Framework for the years 2007-2013 it is a widely accepted fact that the status quo of the EU system of own resources suffers from several shortcomings. In the new framework, the virtually contribution-based system with the predominant role of the GNI-proportional "fourth" resource, supplemented by the "traditional own resources" 
comprising excise and agricultural duties and the VAT resource ${ }^{1}$, has been maintained. ${ }^{2}$ Moreover, apart from the UK rebate which exists since the Fontainebleau agreement in 1985, abatements were introduced for four other countries (the Netherlands, Sweden, Germany and Austria). ${ }^{3}$ Since the Heads of State and Government themselves had to acknowledge the limits of the budgetary settlement, they agreed on "a comprehensive reassessment of the Financial Framework, covering both revenue and expenditure" which is set to take place in the years $2008 / 09$. This review will offer the opportunity for fundamental reflections on reforms without the urgent pressure to arrive at a final decision immediately. In this sense the review can be seen as a chance to develop options that will then be available at the next settlement which is due by the end of the current Financial Framework.

One of the main shortcomings which is usually associated with the current own resources system is the "missing link to the citizens": The system has become increasingly complex in the course of time, so that the citizens are by no means able to understand it anymore and do not get an impression of the true costs of European integration (and hence overestimate them in the eyes of integration supporters). Moreover, the system is characterised by an inflation of rebates and special provisions, with the UK rebate as the most famous example. These abatements however damage the EU's credibility, undermining the perceived fairness and acceptance of the system. Further, the "juste retour" thinking of national governments is often the focus of the criticism of the current system. The use of national contribution payments would fix the national budgetary net positions, neglect genuine European demands and lead to political conflicts.

While the need for reform is thus widely undisputed, its direction is up for discussion. One option which would imply far-reaching changes compared to the status quo would consist in a tax directly payable to the EU, constituting a genuine "own resource". But this proposal also provokes the most controversial discussions among academics, politicians and the broad public. While supporters of this "EU tax" expect a solution for several deficiencies of the status quo, opponents fear and criticise the increasing fiscal burden for the citizens.

1 It should be clarified that the current VAT resource is a financial contribution (based on a harmonised tax base which is calculated exclusively for this purpose). As a consequence, the member states do not transfer a certain share of their VAT revenues to the EU.

2 See European Council: Financial Perspective 2007-2013, Brussels, 16. 12. 2005.

3 These abatements comprise reduced rates of call of the VAT resource for all four countries, as well as lump-sum reductions for Sweden and the Netherlands. 
In the existing literature, the suitability of an EU tax is usually assessed in an unambiguous manner. Le Cacheux, for example, puts forward strong arguments in favour of an EU tax, ${ }^{4}$ while Caesar argues rigorously against it. ${ }^{5}$ Although it will become clear that we tend to see an EU tax in a negative light, the theoretical arguments of both groups will be confronted in the following. After a short overview of the general design of an EU tax (II.), the well-known pros and cons will be systematised in the ensuing sections and enriched by some rather unknown arguments (III. and IV.). Section V. is devoted to the potential implementation of relevant reforms, which is usually neglected in the discussion. For this purpose, it will be examined if the different proposals are enforceable, especially in the light of the required approval by all national governments represented in the European Council.

\section{Overview of Frequent EU-Tax Proposals}

A tax-based EU "own resource" presupposes two choices, which are mutually interdependent: (1) the design of the tax system and (2) the choice of a tax base. Regarding the first choice, Raddatz and Schick (2003) present three different concepts of how a tax-based system of own resources might be designed. ${ }^{6}$ These designs mainly differ in the degree of harmonisation of the tax systems.

The highest degree of harmonisation is needed in a linked system in which the EU receives a share from the revenues of a certain tax levied in all member states in a uniform way. Such a system requires both the tax bases and the tax rates to be identical in order to guarantee horizontal equity between EU citizens. The second alternative, the surcharge system, requires less harmonisation. For this option only the harmonisation of the tax base is required; the EU would have the autonomy to levy a uniform EU-wide rate in addition to the national rates which might differ. These two designs are relevant for taxes whose revenues exceed the amount attributed to the EU. In a separation system, the third concept, the EU would have the full and exclusive autonomy to tax a specific base. This design would be highly relevant in case of an introduction of a new EU tax which does not yet exist in the member states.

4 Le Cacheux, J.: Funding the EU budget with a Genuine Own Resource: The Case for a European Tax, Notre Europe Studies no.57, 2007.

5 Caesar, R.: An EU Tax? - Not a Good Idea, in: Intereconomics, 36/5 (2001), 231-233.

6 Raddatz, G. K./Schick, G.: Wege zur europäischen Verfassung III - Braucht Europa eine Steuer?, Argumente zu Marktwirtschaft und Politik no. 77, Stiftung Marktwirtschaft, Berlin, 2003. 
Regarding the choice of the tax base, several authors reach at quite different conclusions. However, all supporters have one feature in common: Nobody argues that their preferable alternative is the "perfect" solution for an EU tax as every option has its specific problems. In the most prominent proposal, the European Commission suggests the introduction of a tax-based own resource by 2014 and offers three "main candidates": energy consumption, a modulated value added tax (VAT) and a corporate income tax. ${ }^{7}$ Recent comments by Tax Commissioner Kovács suggest that the Commission favours the idea of a modulated VAT. ${ }^{8}$ An expert advisory board set up by the former President of the European Commission, Romano Prodi, and led by the former French Minister of Finance, Dominique Strauss-Kahn, regarded company taxation as the "'natural' candidate". 9 Another influential report of the Commission, the Sapir Report, mainly demands the allocation of sources with a clear EU dimension and argues that ECB seigniorage, capital income taxes and stock exchange taxes fulfil this criterion. ${ }^{10} \mathrm{~A}$ recent analysis by the Austrian research institute WIFO supports the idea of a tax on financial transactions and a kerosene tax. ${ }^{11}$ The former Austrian Chancellor Wolfgang Schüssel proposed exactly these two alternatives in his role as President of the European Council. ${ }^{12}$ A further proposal comes from three German Members of Parliament of the Green Party suggesting to finance the budget with harmonised gasoline taxes in the middle run and in the long run with revenues from emission trading or corporate taxes. ${ }^{13}$ In academics, it is not uncommon to find considerations based on scores reflecting the advantages and disadvantages of certain alternatives. For example, Begg and Grimwade propose the introduction of a modulated VAT own resource complemented with communication taxes. ${ }^{14}$ Gros and Micossi also argue in favour of VAT but propose the

7 European Commission: Financing the European Union, Commission Report on the Operation of the Own Resources System, DG XIX, Brussels, 2004.

8 Kovács, L.: Kommissar treibt EU-Steuer voran, in: Financial Times Deutschland of 03.03. 2006.

9 Strauss-Kahn, D.: Building a Political Europe. 50 Proposals for Tomorrow's Europe, Brussels, $2004,94$.

10 Sapir, A.: An Agenda for a Growing Europe: The Sapir Report, Oxford, 2004.

11 Schratzenstaller, M./Berghuber, B.: Finanzierungsalternativen zum EU Budget, Wifo Monatsberichte, 12/2006, 893-910.

12 Schüssel, W.: Presentation of the Austrian Presidency's Programme, Speech by the President of the European Council, Federal Chancellor Wolfgang Schüssel, Brussels, 18. 01. 2006.

13 Lührmann, A./Schick, G./Steenblock, R.: (2006), Grüne Vorschläge zur Reform der EU-Finanzierung, Bundestagsfraktion Bündnis 90/Die Grünen, Diskussionspapier, Berlin, 2006.

14 Begg, I./Grimwade, N.: Paying for Europe, Sheffield, 1998. 
perpetuation of GNI resources as means to absorb shocks. ${ }^{15}$ El-Agraa presents a model for designing an EU personal income tax. ${ }^{16}$ Other academics explicitly demand a mix of resources in order to offset the disadvantages created by a single resource. ${ }^{17}$ Cattoir lists the most often proposed candidates for an EU tax. ${ }^{18}$ They include direct taxes, i.e. (1) corporate income tax and (2) personal income tax, as well as indirect taxes, e.g. (3) VAT, (4) excise duties (on tobacco or alcohol), (5) energy taxation (on kerosene, motor fuel or $\mathrm{CO}_{2}$ emissions), (6) taxes on financial transactions and (7) communication taxes (on telephone lines or air and road transport). Other influential analyses, such as the Lamassoure Report of the EU Parliament, ${ }^{19}$ remain vague with regard to their preferred tax.

The following discussion will concentrate on the general suitability of tax-based own resources. A detailed presentation of these proposals for an EU tax is dispensable since extensive evaluations of single taxes can be found elsewhere. ${ }^{20}$ These authors initially derive an evaluation scheme, including criteria like transparency or autonomy, and then give different weights to single criteria. In contrast to this approach, we do not summarise the discussion according to the pros and cons of the proposed EU taxes, but try to systematise the debate according to the main arguments raised in favour of (III.) and against (IV.) an EU tax. The distributive consequences of these different types of EU taxes are simulated in section V., as it may be assumed that they are crucial from the perspective of national governments for the evaluation of a tax-based system of own resources.

\section{The Pros}

This section presents arguments which are usually put forward in favour of the introduction of an EU tax. Moreover, they are critically discussed, since it is often neglected that several arguments in favour of tax-based own resources are

15 Gros, D./Micossi, S.: A Better Budget for the European Union - More Value for Money, More Money for Value, CEPS Policy Brief no.66, Brussels, 2005.

16 El-Agraa, A.M.: The General Budget, in: id. (ed.): Economics of the European Community, $3^{\text {rd }}$ ed., Cambridge, 1990, 286-303.

17 Goulard, S./Nava, M.: A more Democratic System for Financing the EU Budget: A Challenge for the European Convention, mimeo, Brussels, 2002.

18 Cattoir P.: Tax-based EU Own Resources: An Assessment, European Commission Taxation Papers, no. $1 / 2004$.

19 Lamassoure, A.: Draft Report on the Future of the European Union's Own Resources, European Parliament Committee on Budgets, 2006/2205(INI).

20 Cattoir, P., op.cit.; Euler, M.: Ansatzpunkte für eine Reform des Finanzierungssystems der Europäischen Union, Frankfurt a. M., 2005; Le Cacheux, J., op. cit. 
only valid for a restricted number of taxes and that several features of tax-based own resources - which are regarded as "improvements" of the status quo - are not as undisputed as they are described by their supporters.

Visibility: One of the most popular arguments put forward by advocates of an EU tax is the increase of transparency of the budget. Indeed, it is generally acknowledged that the current system of own resources with its multitude of revenue sources and abatements performs poorly regarding transparency. Thus, citizens are not able to assess their contribution to the EU and the added value of EU politics. It is claimed that this deficiency contributes to the Union's democratic deficit. The weak role of the European Parliament enforces this deficit. Goulard and Nava state that the EP "is the only parliament in the world that debates expenditure but has no competence to determine the revenue that must be collected in order to finance that expenditure" ${ }^{21}$. This view claims that if the Parliament was not only responsible for the expenditures but also for the revenues, the involvement of the citizens in European policies would be strengthened.

At least two qualifications are important with regard to this argument. First, transparency may be a necessary but not sufficient condition for budgetary discipline. Another important factor is the existence of good institutions, setting balanced incentives to political decision-makers with regard to both the benefits and the costs of spending. ${ }^{22}$ Secondly, it has to be asked which taxes are actually visible to the citizens. In this respect, it is often neglected by supporters of an EU tax that this criterion is not met by every tax which is up for discussion. From the tax options mentioned above, we only regard taxes which are tangible for the vast majority of the citizens appropriate to increase visibility, but not those taxes which only affect a small portion of the tax payers. Thus, the choice would be reduced to VAT, personal income taxes and, with limitations, excise taxes on gasoline. Huber (2001) goes even further and argues that only a direct tax like a personal income tax would be tangible for the citizens while indirect taxes would only have an impact through higher consumer prices and, thus, would not be tangible. $^{23}$

21 Goulard, S./Nava, M., op. cit., 10.

22 See e.g. Hagen, J.v.: Fiscal Rules, Fiscal Institutions, and Fiscal Performance, in: The Economic and Social Review, 33/3 (2002), 263-284.

23 Huber, B.: Zur Finanzierung der Europäischen Union, in: Zeitschrift für Wirtschaftspolitik, 50/1 (2001), 49-58. 
Other taxes that are exclusively imposed on companies or small groups of people, such as smokers or consumers of alcohol, can obviously not fulfil the criterion of tangibility so that they are not visible to all citizens. They would not be "recognisable and identifiable as such by the public", as one of the supporters of an EU tax, former Budget Commissioner Michaele Schreyer, demands. ${ }^{24}$ Moreover, the postulate of horizontal and vertical equity would be violated by the introduction of taxes that are imposed on a small part of the EU population. Especially excise taxes on alcohol and tobacco mainly hit poorer citizens who consume relatively more of these goods, leading to a regressive effect. ${ }^{25}$ Furthermore, the principle of horizontal equity is hurt as the financing is only borne by a small part of the society, for example, smokers. Both would have a negative effect on the citizens' attitude towards European integration since this would lead to the feeling that only a small, not prosperous group of the society is responsible for the financing of the EU.

Nevertheless, it would be advantageous if the citizens were able to assess the costs connected with EU membership. However, it is doubtful whether the visibility of the costs of the EU would effectively increase the popularity of EU institutions as claimed by many proponents of an EU tax. As a recent Eurobarometer survey (2006) shows, only $11 \%$ of the respondents stated that the replacement of the national income tax by a European one would strengthen their feeling about being a European citizen. ${ }^{26}$

A key assumption of many proponents of an EU tax is that people overestimate the burden nowadays because they are not able to quantify the costs of the EU. ${ }^{27}$ However, this view is also problematic: If more visibility leads to a better assessment of the costs of the EU, public support of the EU may even decline, once citizens are confronted with their individual burden from EU spending. This view seems to be also shared by the Commissioner László Kovács who promoted the use of VAT as an EU tax and stated that direct taxes had direct effects on citizens and companies and therefore caused an anti-EU sentiment. ${ }^{28}$ Consequently, a highly tangible tax would possibly have a negative impact on the citi-

24 Schreyer, M.: The Own Resources System Needs Rethinking, in: Intereconomics, 36/5 (2001), 223-225, here 225 .

25 Within a national tax system, regressive taxes are not problematic per se, but even desirable when they fulfil an incentive function.

26 Eurobarometer: The Future of Europe, Special Eurobarometer 251/Wave 65.1, Brussels, May 2006.

27 Goulard, S./Nava, M., op. cit.

28 Kovács, L., op. cit. 
zens' attitudes towards integration, while increasing transparency at the same time. As Goulard and Nava point out, this would mainly affect newly introduced taxes as "any new tax would be unpopular", which makes them unsuitable for integration enhancing goals. ${ }^{29}$

Autonomy: An increase in autonomy is one of the main arguments in favour of an EU tax. ${ }^{30}$ However, even official statements do not indicate how far this autonomy should go and whether it would be identical to fiscal sovereignty in the sense that EU institutions are allowed to increase the rate of a tax once it is assigned to them. Although political autonomy is often associated with revenue competences, many politicians beyond Brussels still oppose such powers for the EU.

We hold the view that autonomy is not an end in itself as this claim could simply reflect the ambition of European institutions to increase their influence. Nevertheless, one general advantage is often granted to transferring revenue competences to the EU: The reliability of EU revenues could be secured in this way, because financing systems based on national contributions always imply a certain blackmail potential by member states. ${ }^{31}$ This problem is highly virulent in international organisations, such as the $\mathrm{UN}$, on which the member states put pressure by withholding their contributions in order to achieve certain political goals.

However, it is doubtful whether this argument is valid to give support for an EU tax. First, withholding of EU payments is still a violation of binding international contracts; therefore, due to its legal deterrence, the danger of holding back revenues seems to be low compared to international organisations. Moreover, the introduction of an EU tax would not reduce this danger. For none of the taxes discussed above the Union would be able to collect the tax by itself, but rely on national administrations. In this case, the possibility to withhold payments would be as high as in the case of national grants. Therefore, an EU tax would hardly make a difference compared to the status quo in this regard.

Public Choice aspects: Several authors argue that the pressure on budgetary expansion caused by factors which are well-known from the public choice literature, such as the common pool problem and bureaucratic self-interest, may be

29 Goulard, S./Nava, M., op. cit., 18.

30 See, for instance, European Commission, op. cit., 11.

31 Begg, I.: Future Fiscal Arrangements of the European Union, in: Common Market Law Review, 41/3 (2004), 775-794. 
best met by increasing the Parliament's autonomy through the introduction of an EU tax. In formal terms, Biehl derives the "correspondence principle" from the theory of fiscal federalism in order to achieve a more efficient EU budget. ${ }^{32}$ This principle claims "fiscal equivalence", i.e. the identity of a "match between those who receive the benefits of a collective good and those who pay for it" as it was already introduced by Olson..$^{33}$ Following this view, the European Parliament as the authority responsible for expenditures should also be responsible for the decision-making on how to finance the EU budget. As this would increase the accountability of MEPs to their voters, it would put pressure on a more efficient budget.

But this view of an increase in budgetary discipline through an EU tax is too simplistic. It is problematic to assume that the assignment of tax powers to the European institutions would automatically lead to a more efficient budget. MEPs would retain the incentive to fight for pork barrels for their countries or regions because they do not internalise the full costs which have to be borne by the common pool consisting of the overall resources generated by all EU citizens through the payment of the EU tax.

In addition, inefficient budgetary outcomes could also result from a reduced tax competition. Following the view of Brennan and Buchanan, tax competition serves as a constraint to the tendency of public institutions to maximise the budget. ${ }^{34}$ The assignment of a tax to the EU as the highest tier of government would imply a complete harmonisation and hence, disable competition regarding this tax. Tax revenues could then be increased by European politicians without having to fear negative effects due to evasion within the EU.

Moreover, it can be doubted whether the control of the European institutions by the people, i.e. checks and balances, is sufficient, as "European voters have practically no means of sanctioning EU policy makers for 'bad' budget decisions" ${ }^{35}$. By contrast, Raddatz indicates that a decentralised structure will decrease the room for manoeuvre for politicians and bureaucrats resulting in a more effective realisation of voters' preferences. ${ }^{36}$ The interest of the citizens in EU affairs is by

32 Biehl, D.: An Economic Perspective, in: Hesse, J. J./Wright, V. (eds.): Federalizing Europe? The Costs, Benefits, and Preconditions of Federal Political Systems, Oxford, 1996, 101-120.

33 Olson, M.: The Principle of "Fiscal Equivalence": The Division of Responsibilities among different Levels of Government, in: American Economic Review, 59/2 (1969), 479-487, here 483.

34 Brennan, G./Buchanan, J.M.: The Power to Tax, Cambridge, 1980.

35 Caesar, R., op. cit., 232.

36 Raddatz, G. K.: Das Eigenmittelsystem der Europäischen Union, Frankfurt a. M., 2005, 105. 
far not as pronounced as at the national level. This may limit the effective control of EU politicians. As a consequence, there is a real danger that giving more revenue autonomy to the European Parliament would lead to an inefficient increase of spending.

Finally, the substitution of national contributions would lower national governments' incentives in constraining the EU budget. This is one positive feature of the current system, as the member states (especially the net payers) have a strong interest in capping the EU budget because the European and the national budgets are directly linked. If the EU budget is reduced, the national budget is increased by the national share of the reduction. Introducing a European tax would destroy this link and increase the danger of overspending.

Political struggles: Among others, the European Commission argues that the "juste retour" thinking can be overcome by the introduction of an EU tax which would create "a sufficient degree of autonomy from national treasuries to reduce the tendency towards a narrow focus on national interest" ${ }^{37}$.

However, it is questionable whether the assignment of a revenue source to the EU would automatically end the "juste retour" discussion. Although the national payments would no longer be directly displayed, it would be an easy task to calculate the national shares from their tax payments to the EU. As any EU tax would be collected by national authorities, the calculation of national contributions would still be possible. ${ }^{38}$

Another aspect is that taxation by EU authorities may serve as a scapegoat for national politicians. They might blame the Union for the fiscal burden of their citizens, which would even increase the conflict potential between member states and European institutions. Moreover, the major redistributing effects from the budget do not arise from the revenue but mainly from the expenditure side, with its focus on redistributive payments for the common agriculture policy and structural policy. Most political struggles regarding the revenue side, for instance, in the discussion on the new Financial Framework, did not arise because the revenue side served as counterpart to the expenditure side with its partly unsystematic redistributive effects, which consequently led to several abatements for countries which are discriminated on the expenditure side. Thus, the most effi-

37 European Commission, op. cit., 11.

38 Mutén, L.: The Case for an EU Tax is not Convincing, in: Intereconomics, 36/5 (2001), 228-230. 
cient reform to avoid further struggles should take place on the expenditure side. $^{39}$

Regional arbitrariness: Generally, there is no close connection between the regional revenue of a fiscal source and the true economic regional distribution of its burden. If a revenue source is characterised by regional arbitrariness, this will give strong support to its assignment to the highest level of government. This argument is also sometimes used to justify an EU tax. However, this problem only affects very few taxes where it is not possible to assign the revenues at least roughly to the countries. Corporate and capital transaction taxes are taxes where regional arbitrariness is sometimes put forward as an argument for an EU tax. ${ }^{40}$ The intuition behind this is that gains of multi-national companies are often not taxed in the country of their creation. However, the argument is not as convincing as in the case of traditional own resources, where revenues directly result from European policies and where the national revenue is a very poor indicator for a country's true economic burden. As a consequence, we think that this is not a sufficient reason for the assignment to the EU.

Fiscal externalities: Another argument often put forward in favour of assigning a certain tax to the level of the EU stems from the existence of fiscal externalities. This mainly affects taxes with a very mobile tax base, namely the taxation of interest or corporate income. But it is controversial whether competition for mobile tax bases or its elimination - which would be the consequence of the introduction of an EU tax - is desirable. While its opponents warn against too much pressure on national budgets if the countries' tax systems compete for mobile factors, the proponents of more decentralised taxation stress the positive effect of competition as a constraint of the politicians' and bureaucrats' tendency to over-taxation. ${ }^{41}$

Even if there were a consensus within the EU that competition for certain taxes is not desired, it would not necessarily mean that the centralisation of the tax should be strived for. Instead, the member states may agree on certain minimum tax rates, thus reducing the degree of unwanted tax competition while still granting them a certain degree of autonomy to allow for diverging national preferences. Apart from that, it should not be neglected that the EU member states do

39 Caesar, R., op. cit.

40 Schratzenstaller, M./Berghuber, B., op. cit.

41 See e.g. Edwards, J./Keen, M.: Tax Competition and Leviathan, in: European Economic Review, 40/1 (1996), 113-134. 
not only compete with other EU members for mobile tax bases but also with nonEU countries. Therefore, potentially harmful competition would not be completely eliminated but be reduced at best.

As differences regarding taxation between member states lead to cross-border shopping, fiscal externalities are also often assumed in the case of VAT, excise duties or petrol taxes. This is also seen critical due to its negative effect on the environment because of additional traffic. But as analogical evidence shows, ${ }^{42}$ this only happens in regions close to national borders and generates comparatively low fiscal externalities, which cannot justify the complete harmonisation through the assignment of these taxes to the EU level.

\section{The Cons}

The proposal to introduce an EU tax has often been criticised both in the academic and in the political debate. In the following, several often-cited deficiencies of an EU tax as well as some rather new arguments against it are discussed.

Increasing financial burden: Supporters of an EU tax claim that any reform of the system of own resources should not be accompanied by an increase in the financial burden of the citizens ${ }^{43}$ or ensure "cost neutrality" ${ }^{44}$. The Lamassoure Report even demands that this should be ensured by the supervision of the national and European Courts of Audit. ${ }^{45}$ However, there are at least two arguments which cast the claim of cost neutrality into doubt. First, as shown above, it is unclear whether the increase in financial autonomy of the EU authorities would have a positive or a negative effect on the budgetary discipline. Second, an EU tax necessarily limits tax competition for the involved type of tax. Advocates of tax competition argue that any such step would simplify the financing of budgetary expansion.

The reduction of tax competition would depend on the quality of harmonisation steps involved. The harmonisation of a certain tax base for the purpose of establishing a common EU tax would reduce the tax competition between the member states in this area or even eliminate it completely in the case of a linked system,

42 Cnossen, S.: Tax Policy in the European Union: A Review of Issues and Options, in: FinanzArchiv, 58/4 (2001), 466-558.

43 Schreyer, M., op. cit.

44 Haug, J.: More Fairness, Democracy and Transparency!, in: Intereconomics, 36/5 (2001), 226-228, here 227.

45 Lamassoure, A., op. cit. 
which would even mean the alignment of tax rates in such sensitive areas as corporate taxation. A problem may emerge from the introduction of a surcharge system, giving rise to harmful vertical tax competition. Vertical tax competition exists if two or more tiers have unrestricted access to a common tax base through their autonomy to choose the tax rate. Wigger and Wartha discuss this argument analytically. ${ }^{46}$ If no coordination between the different tiers of a federation exists, policy makers with a certain degree of self-serving behaviour do not incorporate the negative externalities of their choice of tax rate on the common tax base and, therefore, on the tax revenue of the other tier which has the right to tax the same base. This might lead to a reciprocal increase of the rates and, consequently, to an excessive taxation which violates both the citizens' preferences as well as the claim for efficiency.

Moreover, any model of an EU tax presented above assumes that the abolition of national contributions would be completely passed to the citizens through a reduction of national taxes, so that the level of their overall fiscal burden will be maintained. But from a public choice perspective, self-interested politicians might use this occasion to raise their revenues by not passing all of their saved contributions. This may allow them to increase their tax revenues and blame the EU for the tax increases; as Caesar holds it, this would be "a very comfortable excuse" ${ }^{\prime 47}$. This danger would be most marked in the case of a new tax which is fully assigned to the EU. If an existing tax (or parts of it) was assigned to the EU, this would automatically reduce the national tax revenues by the same amount. In the case of a new tax, however, the money saved by the national governments would call for the cut of other taxes, which might be resisted by the politicians as the tax increase at national level would not be visible to the citizens.

Preferences: Any option of a tax-based own resource demands a certain degree of harmonisation. This might only affect the tax base (surcharge system) or both tax base and rate (linked and separation system). In any case, this will lead to inefficiencies if the preferences for taxation differ between the member states. As it is shown by Heinemann et al., tax preferences indeed appear to be substantially heterogeneous in Europe so that this argument is empirically valid. ${ }^{48}$ This prob-

46 Wigger, B. U./Wartha, U.: How to Allocate the Power to Tax in Europe?, in: Holler, M. J. (ed.): European Governance, Tübingen, 2003, 173-190.

47 Caesar, R., op. cit., 233.

48 Heinemann, F./Mohl, P./Osterloh, S.: Reform Options for the EU Own Resources System, Heidelberg, 2008. 
lem is especially severe within a linked system as it demands the harmonisation of both the tax base and the tax rate.

Interference with national federal structures: In several countries of the EU, lower tiers of government have the right to levy certain taxes. These domestic relationships of fiscal federalism would be disturbed by the introduction of EU taxes. For example, Germany would be affected insofar as the revenues of some taxes proposed to be assigned to the EU do not accrue to the federal government but to the Länder or are shared among both. This mainly affects the VAT, the personal and the corporate income tax, which are shared among both levels.

The assignment of one of these taxes to the EU would, thus, reduce the tax revenues of the lower tiers of government in the respective states and limit their autonomy in cases where the lower tiers today have the autonomy to set the tax rate. Then, a rearrangement of the domestic responsibilities between the different tiers would be unavoidable, which would meet with strong disapproval by regional politicians and cause further adjustment costs in the affected countries.

Compliance costs: Any new tax to finance the EU would automatically be connected with increasing administration costs. The assignment of an existing national tax to the EU would entail additional costs as well. These would be caused by higher administrative effort due to the monitoring by the EU which would be necessary to prevent fraud. The EU would have a vital interest in imposing very strict controls of the national tax administrations because it could not accept national differences in collection efficiency. These could emerge due to principle-agents problems as the national institutions would not participate in the levied revenues and, therefore, not have a strong interest in strict controls anymore. Any difference in collection efficiency would cause unequal national contributions and could lead to struggles between the member states about an unfair sharing of the financial burden. These controls would cause very high costs in relation to the additional benefits which would arise from the monitoring as it may be assumed to be the case of today's levy of the Traditional Own Resources (TOR).

Apart from that, additional costs would also arise before the introduction of an EU tax largely due to the indispensable full harmonisation of existing tax bases. As it is discussed in the literature, ${ }^{49}$ there are major differences regarding the current degree of harmonisation of the candidates for an EU tax. There are only 
few tax options which have already highly standardised tax bases, e.g. excise duties on alcohol, tobacco or petrol.

Sufficiency: From the group of taxes proposed as EU taxes, there are only very few that fulfil the criterion of sufficiency. However, this criterion must be cautiously applied since scarcity of revenues has the advantage of constituting a hard and disciplining budget constraint. Nevertheless, taxes whose revenue would by far not cover the budgetary needs have the obvious disadvantage that numerous different sources would have to be combined. This would not serve the claim of visibility as an increasing number of resources automatically increase the complexity of the system, thus, reducing its transparency.

Cattoir estimates the maximal shares of GNI that different resources can supply to: tobacco $0.7 \%$, alcohol $0.3 \%$, airport tax $0.1 \%$, telephone lines $0.1 \%$, aviation charge $0.1 \%{ }^{50}$ Hence, the consideration of one of these taxes necessitates the use of further revenue sources and would, thus, be confronted with the need to establish a system based on a multitude of revenue sources.

In addition, several tax proposals would not guarantee sufficient resources in the long-run even if the share of the EU expenditure in GNI would remain stable over time. As VAT revenues grow slower than GNI, the use of this tax as own resource would require frequent adjustments of the call rate to ensure the endowment with sufficient resources. ${ }^{51}$

Flexibility: One problem of all proposed tax options compared to a system based on national contributions is that they are fixed regarding the degree of progressiveness. Once introduced, the degree of redistribution is determined according to the national shares in the agreed tax base; future changes would result from changing national shares in the tax bases but cannot be influenced by changing the EU-wide identical tax rate. However, an adjustment of the progressiveness on the revenue side might become desirable in the long term due to changes on the expenditure side or changed preferences for redistribution.

Stability: As a matter of fact there is no tax option which would be able to ensure the same degree of stability of revenues for the EU budget as the GNI resource does today. Any tax is, to a certain extent, unpredictable in terms of its revenues, thus, showing higher volatility and resulting in either too low or too high revenues. Both business cycles and structural changes in the economy have an impact 
on tax revenues. Business cycle effects are strongest for corporate income taxes while VAT or excise duties show the highest stability over the business cycle but may be affected by other trends like world trade growth or changes in consumption.

Budgetary balance: Apart from the controversial question whether the advantages of an EU tax would outweigh the disadvantages, the introduction of a purely tax-based system of own resources (plus the TOR) would technically not be feasible within the existing framework which prescribes a balanced budget for every year, since there is no tax imaginable whose revenues are flexible enough to exactly match the amount of money which is fixed by the Financial Framework. In the following, some options discussed in the literature to solve this dilemma are presented, which are all connected with further problems.

GNI as residual: The option that is implicitly or explicitly included in most proposals for a tax-based system of EU own resources is the perpetuation of the GNI resource as residual. This means that the GNI resource would keep the same role as it has today, i. e. balancing the difference between a cyclical resource (today: VAT resource) and the amount of spending fixed by the Financial Perspective. Although the maintenance of the GNI resource as residual seems to be the most adequate way to establish a tax-based system of own resources, several difficulties arise.

One main disadvantage would be the major reduction of visibility. The number of resources would stay the same as in the status quo (while the EU tax replacing the VAT resource), which would not contribute to an increase in simplicity. ${ }^{52}$ Moreover, the GNI resource would necessarily continue to be of major importance in order to create a buffer large enough to cope with the volatility of the EU tax. Obviously, only a part of the revenues would be visible to the citizens through their tax payments giving them a wrong impression of the true costs of the Union. Consequently, the additional gain of the EU tax concerning visibility would be limited.

Right to borrow: Another option often put forward to solve the problem of unstable revenues is to grant the EU the right to borrow if the revenues are lower than the expenditure due to cyclical effects. This would enable the EU to choose a tax which balances the budget in an average year, thus, avoiding the use of a

52 Fehr, H.: Der Haushalt der Europäischen Union - Aktuelle Entwicklungstendenzen und Reformoptionen, in: Zeitschrift für Wirtschaftspolitik, 50/1 (2001), 36-48. 
further residual resource. In addition to that, economists may justify the right to borrow with several other features. ${ }^{53}$ In that respect, mainly the Keynesian view of a stabilisation function in order to smooth the business cycle is mentioned. However, this view is highly controversial as the current amount of the budget is far too low to have a stabilising impact.

Assuming self-interested public agents, as the public choice literature does, granting the EU the right to borrow needs to be critically assessed. This would automatically lead to a relaxation of the budget constraints and raises the pressure towards an increase of the budget. As Caesar stresses, this problem would be even more severe than at national level as the EU lacks an effective mechanism that would impose sanctions on the parliamentarians and counteract an increase in the budget. ${ }^{54}$ Furthermore, the Union would - at least initially - face even less capital market restrictions than member states with lower ratings. Thus, it seems justified that a deficit competence is rarely mentioned as a reform option for the EU own resource system.

Increase of flexibility on spending side: A further way to cope with the variability of the revenues of an EU tax is to make the spending side more flexible. This would mean the reversal of the current situation where the fixed expenditure side determines the amount of revenues. Instead, the collected tax revenues would determine the level of spending. However, such a reform would have to be critically viewed regarding its impact on budgetary discipline. The limitation of spending as achieved through the Financial Framework would be abolished, therefore, the major institutional constraint on the budget size would cease to exist which could open the floodgate for further spending expansion. In view of the "common pool" problem, this would be a worst case scenario. There would be no constraints to limit the incentives of national representatives to strive for increased spending paid out of the common resources provided by the EU tax. Practically speaking, this reform is not compatible with the current policy objectives of the Union as a majority of spending is dedicated to long-ranging projects (especially in the structural funds) which demand stable expenditures.

"Rainy-day fund": A further proposal is put forward by Le Cacheux, who argues for a higher tax rate that would balance the budget even in the case of a reces-

53 For an overview, see Caesar, R.: Zur Reform des Einnahmensystems der Europäischen Union, in: Zolnhöfer, W. (ed.): Europa auf dem Wege zur politischen Union?, Berlin, 1996, 145-173.

54 Ibid. 
sion. ${ }^{55}$ The excessive revenue in "normal" and "good" years will be accumulated in a "rainy-day fund", which would be de-cumulated in times when the tax revenues are insufficient to cover the expenditures.

This option is also problematic as it leads to a softening of the budget constraint, due to the fact that it generates more revenues than fixed in the Financial Framework and, therefore, widens the scope for increasing expenditures. National budgetary policy has hardly ever succeeded in building up reserve funds even under highly favourable conditions. Instead, an extraordinary revenue situation regularly results in new spending. In all likelihood, such a strategy would result in increased spending and a higher burden for the citizens.

\section{The Distributive Consequences of EU Taxes}

A complete evaluation of a potential EU tax has also to take the interests of the players involved in the budgetary process into account. Public choice theory implies that an EU tax would surely find the support of the European Commission and the Parliament as both institutions would gain in importance and prestige. ${ }^{56}$ However, the situation is more ambiguous regarding the European Council and the national parliaments. For them, the distributive consequences are of importance. A problem emerges if the distributive consequences substantially deviate from the current distribution of the contributions, which is roughly proportional to GNI. ${ }^{57}$ In this case, one of the following two consequences would arise:

- One or several disadvantaged countries would use their veto in the Council to avert the introduction of the respective EU tax.

- The Council might still agree on the introduction of the respective tax but, then, only after granting compensations to the negatively affected countries. Thus, the demand for abatements for the affected states would be even higher than today. This development would risk an offset of the (possible) gain in transparency through an EU tax.

55 Le Cacheux, J., op. cit.

56 See Heinemann, F./Mohl, P./Osterloh, S., op. cit.

57 This is due to the dominant role of the GNI-proportional fourth resource which contributed $64.7 \%$ of the budget in 2006. The main exemptions of proportionality are due to the rebates (especially the UK correction), which disburden some of the most prosperous countries and make them pay less than under GNI-proportionality. 
In the following, the distributive consequences of several EU tax proposals are revealed. Although this is a static approach which does not display any price effects or tax-burden shifting, it is still useful to give an impression on the quantitative effects of an EU tax. For this purpose, the distribution of the respective tax base over the member states is estimated and compared with a distribution according to the national shares in GNI. ${ }^{58}$ The resulting change in the partial net balance $X$ is estimated for each country $i$ according to the following formula:

$$
\mathrm{X}_{\mathrm{i}}=\frac{\frac{\mathrm{TB}_{\mathrm{i}}}{\sum_{\mathrm{i}} \mathrm{TB}_{\mathrm{i}}}-\frac{\mathrm{GNI}_{\mathrm{i}}}{\sum_{\mathrm{i}} \mathrm{GNI}_{\mathrm{i}}}}{\frac{\mathrm{GNI}_{\mathrm{i}}}{\sum_{\mathrm{i}} \mathrm{GNI}_{\mathrm{i}}}}
$$

$T B_{i}$ denotes country $i$ 's tax base of a certain EU tax. As the rate of call for the GNI resource is the same for all countries, and as the tax rate of an EU tax is identical for all countries as well, these values cancel out in the calculation and can be omitted. The country's value of $X_{i}$ can therefore be regarded as the percentage change of its contribution payments caused by the shift from GNI proportional contributions to the respective EU tax.

An additional burden (relief) resulting from a specific EU tax is therefore represented by a positive (negative) value. Percentages hence relate to the reference point of GNI proportionality. A value of $+X \%$ for country $i$ for tax $\mathrm{Z}$ means that - compared to a GNI-proportional own resource - country $i$ is confronted with an increase of the financial burden by $+X \%$ in the case of tax $\mathrm{Z}$.

These numbers could also be interpreted in the following way: Assuming that given the redistributive pattern of the expenditures side of the EU budget - GNI proportionality can be regarded as "fair" on the revenue side, the depicted divergence indicates the degree of "unfairness". 


\section{Indirect Taxes}

a) Value Added Tax

Figure 1 shows the distributive consequences of a shift from GNI proportional contributions to payments of a harmonised value added tax. The distribution of the harmonised VAT base has been calculated according to the average national harmonised bases from 2004 to 2006 which are calculated by the Commission for the purpose of the determination of the VAT resource payments. ${ }^{59}$

Figure 1: Distributive Consequences of an EU Value Added Tax

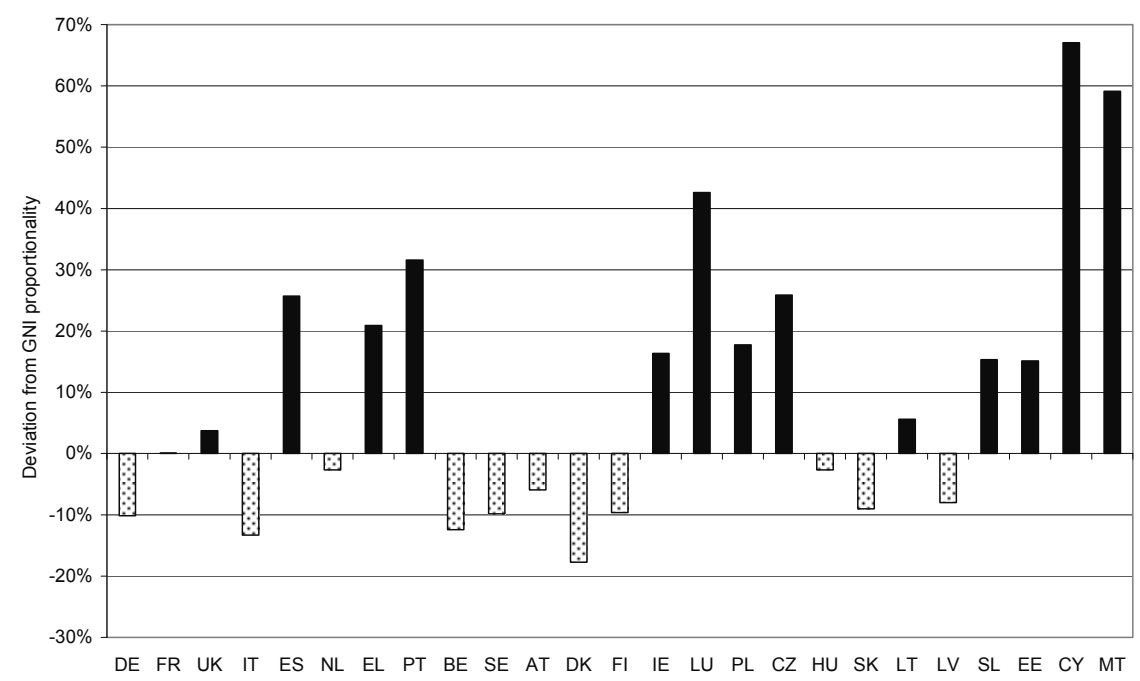

Source: See footnote 59; authors' calculations.

As it can be seen, the introduction of an EU VAT would have major distributive consequences. These range from massively increasing contributions for some countries (e.g., Cyprus, which would have to pay almost $70 \%$ more than under GNI proportionality) to much lower contributions for other countries (almost

59 2004/888/EC, Euratom: Final Adoption of Amending Budget no. 9 of the European Union for the Financial Year 2004, OJEU no. L 383/51 of 28.12. 2004; 2006/5/EC, Euratom: Final Adoption of Amending Budget no. 8 of the European Union for the Financial Year 2005, OJEU no. L 9/73 of 13.01. 2006; 2006/869/EC, Euratom: Final Adoption of Amending Budget no. 4 of the European Union for the Financial Year 2006, OJEU no. L 356/1 of 15. 12. 2006. 
$20 \%$ less for Denmark). Two main drivers for this unequal distribution are noticeable:

- The often-mentioned regressive character of VAT which puts a relatively greater burden on the poorer member states of Southern and Eastern Europe due to a higher consumption ratio;

- The "Marbella" effect, which mainly places a relatively heavier burden on the Mediterranean countries with their higher share of tourism.

These results are not surprising. They are well-known from the debates on the VAT resources and have caused the complications and the essential phasing out of VAT resources since the introduction of the GNI resource as fourth resource in 1988.

\section{b) Excise Taxes}

In Figure 2, the distributive effects of two excise taxes, tobacco and alcohol, are shown. The distribution of the alcohol consumption was calculated based on the estimates of national consumption of pure alcohol per adult in 2003 following Cnossen. ${ }^{60}$ The tobacco consumption was estimated on the basis of the annual cigarette consumption per person according to Mackay et al. ${ }^{61}$

Figure 2 shows immense distributive effects of excise taxes. Both taxes would have extremely regressive effects because the poorer member states from Eastern Europe have the highest consumption of the two taxable goods even on the per capita level. Moreover, national preferences for drinking and smoking influence the relationship between the consumption of these goods and the GNI. A quantity tax may lead to an increase of their EU contributions up to a factor of 12 in these countries and to a halving of the contributions in some Western European member states.

60 Cnossen, S.: Alcohol Taxation and Regulation in the European Union, CESifo Working Paper no. 1821, 2006.

61 Mackay, J./Eriksen, M./Shafey, O.: The Tobacco Atlas, $2^{\text {nd }}$ ed., Brighton, 2006. 
Figure 2: Distributive Consequences of an EU Excise Tax

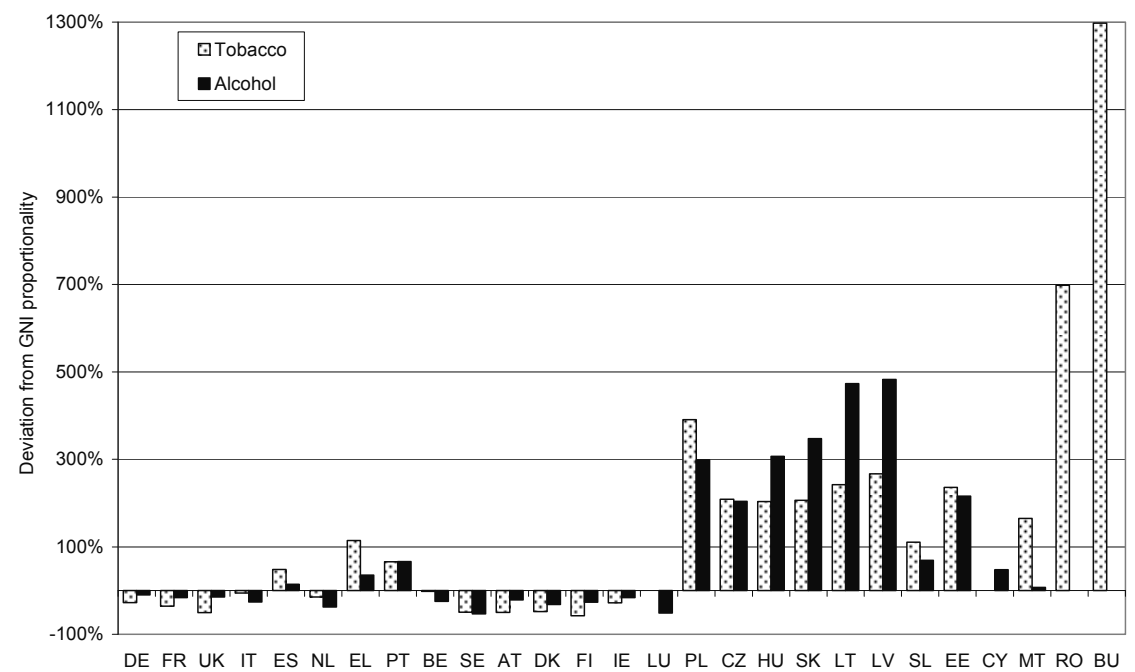

Source: See footnotes $60 \mathrm{f}$; author's calculations.

\section{c) Fuel Tax}

In Figure 3, the distributive effects of an EU fuel tax are shown. The national consumption of fuel is calculated as the sum of the total final consumption of motor gasoline and diesel for transportation (both in 2004) according to the International Energy Agency (IEA) statistics. ${ }^{62}$ In the case of an EU fuel tax, a regressive effect can be observed, too. The Eastern European countries would be again the major losers of its introduction (in some cases burdened with about more than a doubling of their contributions). This reflects that the ratio of fuel consumption relative to GNI decreases with increasing national wealth.

62 These statistics are available at the IEA homepage: http://www.iea.org/Textbase/country/index.asp. 
Figure 3: Distributive Consequences of an EU Fuel Tax

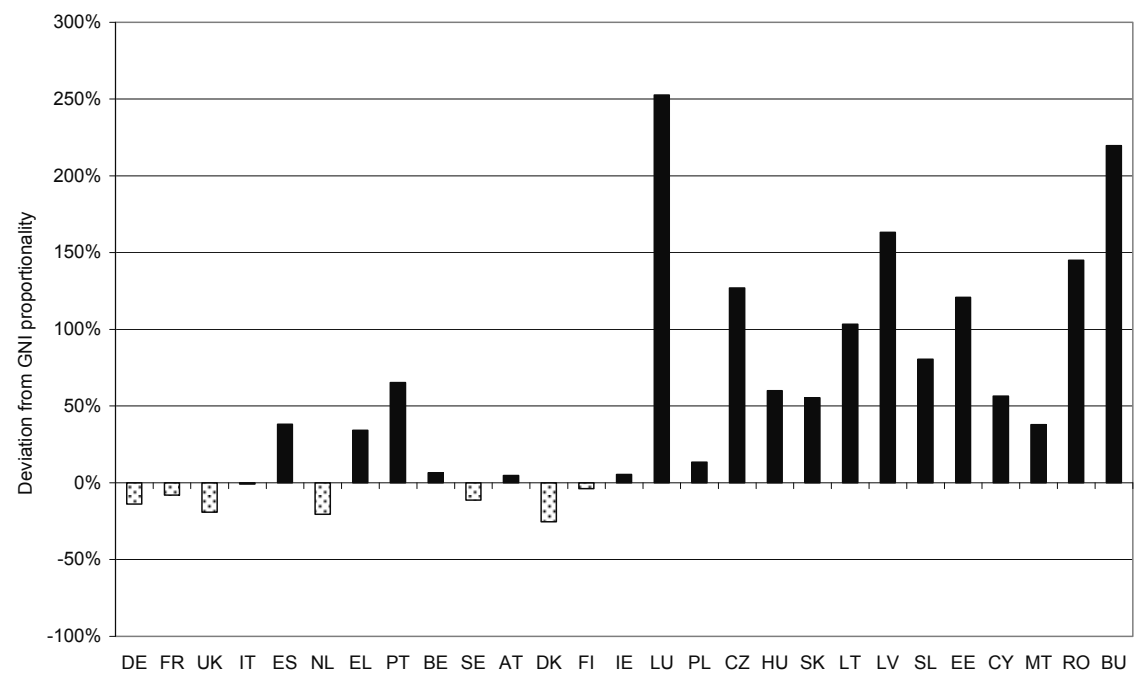

Source: IEA; authors' calculations.

\section{d) Tax on $\mathrm{CO}_{2}$ Emissions}

The effects of an EU tax on $\mathrm{CO}_{2}$ emissions are estimated on the basis of the national $\mathrm{CO}_{2}$ emissions in 2004 and displayed in Figure 4. Like the taxes discussed above, the distributive effect would be a regressive one. It is primarily the Eastern European states that have a high per capita emission of $\mathrm{CO}_{2}$ due to their economic structure. By contrast, Western European countries, like France or Sweden, with a high share of nuclear power would have a significant lower burden. 
Figure 4: Distributive Consequences of an EU Tax on $\mathrm{CO}_{2}$ Emissions

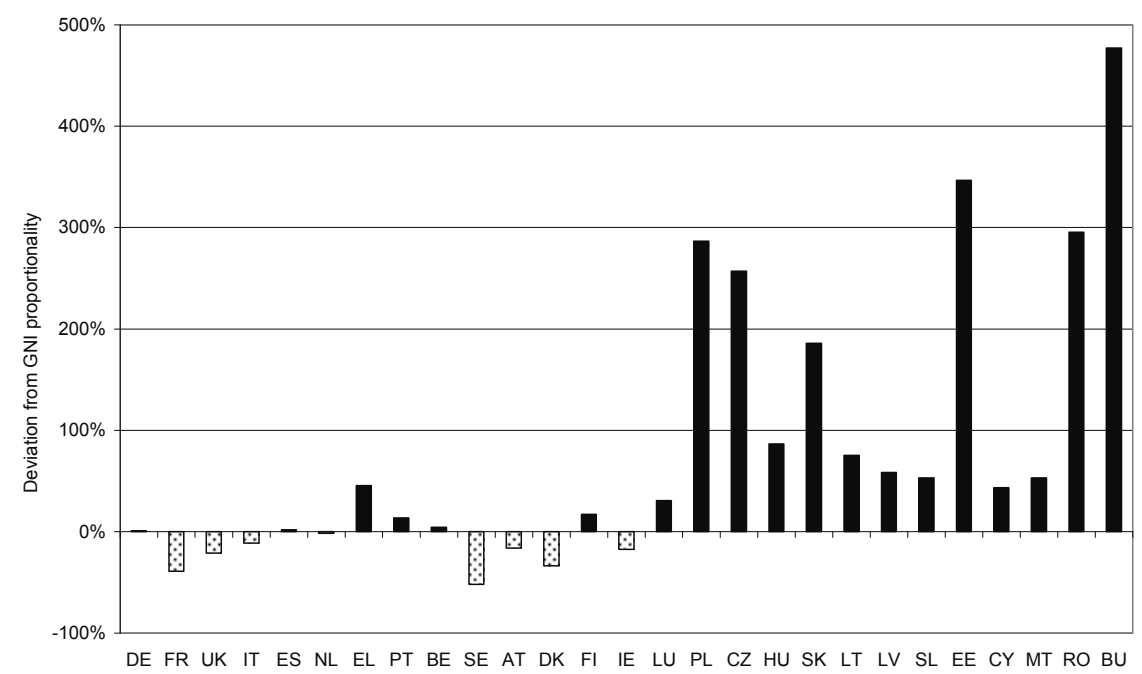

Source: IEA: Key World Economic statistics, Paris, 2006, http://www.iea.org/textbase/nppdf/free/ 2006/key2006.pdf; authors' calculations.

\section{e) Kerosene Tax}

The calculation of the distributive consequences of a quantity tax on kerosene is based on IEA statistics for total final consumption of air kerosene in 2004 (Figure 5). This tax also results in major shifts of the national burdens leading to a quadruplication of the contributions of Cyprus and Malta whose location and tourism industry cause higher-than-average air traffic. Moreover, apart from economies with a high share of tourism, countries with major airline hubs (London, Amsterdam) are negatively affected. In contrast, several countries without major air traffic are almost entirely disburdened from any contributions to the EU.

However, it has to be considered that the incidence of this tax would only partially fall on the citizens of the countries which pay the taxes to the EU but mostly on citizens from other countries using the airports, for instance, tourists from other EU member countries. That notwithstanding, there would still be opposition in the affected countries to a kerosene tax since it exclusively hurts their local industries and, as a consequence, reduces their competitiveness. 
Figure 5: Distributive Consequences of an EU Kerosene Tax

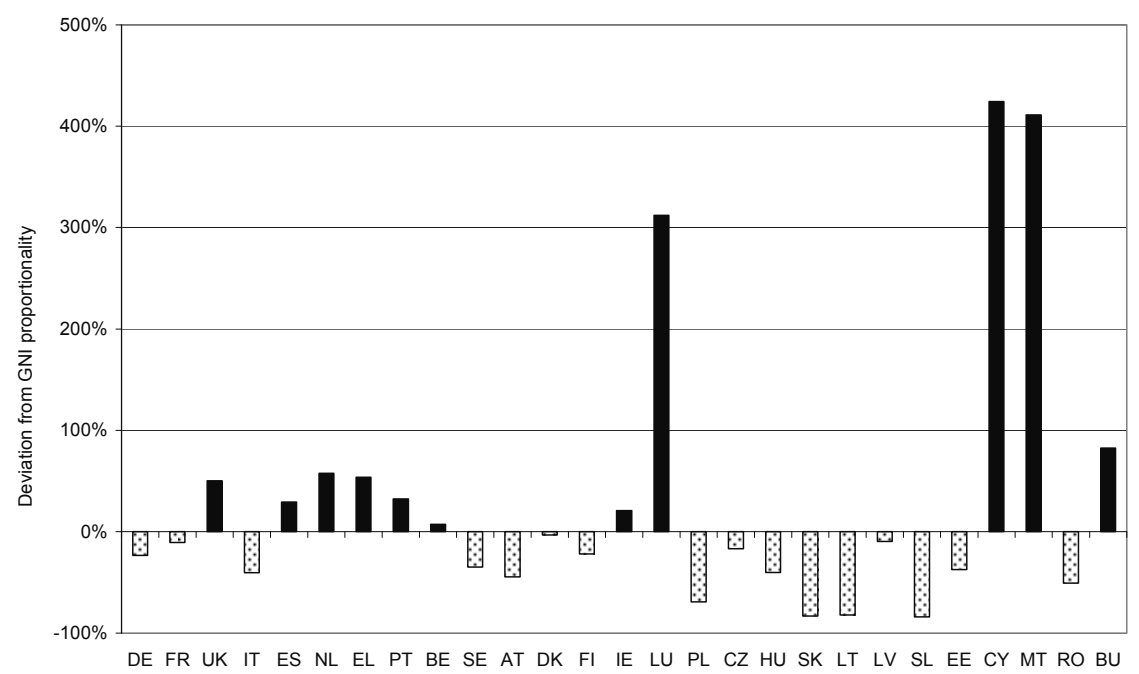

Source: IEA, authors' calculations.

\section{f) Tax on Foreign Exchange Transactions}

Figure 6 shows the distributive consequences of a tax on foreign exchange transactions as proposed by Schratzenstaller and Berghuber and the Austrian chancellor Schüssel. ${ }^{63}$ The distribution of the tax base is calculated from the daily averages of reported foreign exchange market turnover according to the Bank for International Settlement. Remarkably, such a tax would not have a regressive character as most of the other indirect taxes discussed above. Instead, it would excessively burden a couple of countries with important financial markets (in absolute figures mainly the UK with a European market share of almost 2/3) and disburden the overwhelming majority of member states. Similar to the kerosene tax, the incidence of a tax on financial transactions does not fall in full to the citizens of the countries with important market places either. However, these market places would lose much of their competitiveness and, hence, lose market shares to their competitors from overseas. 
Figure 6: Distributive Consequences of an EU Tax on Foreign Exchange Transactions

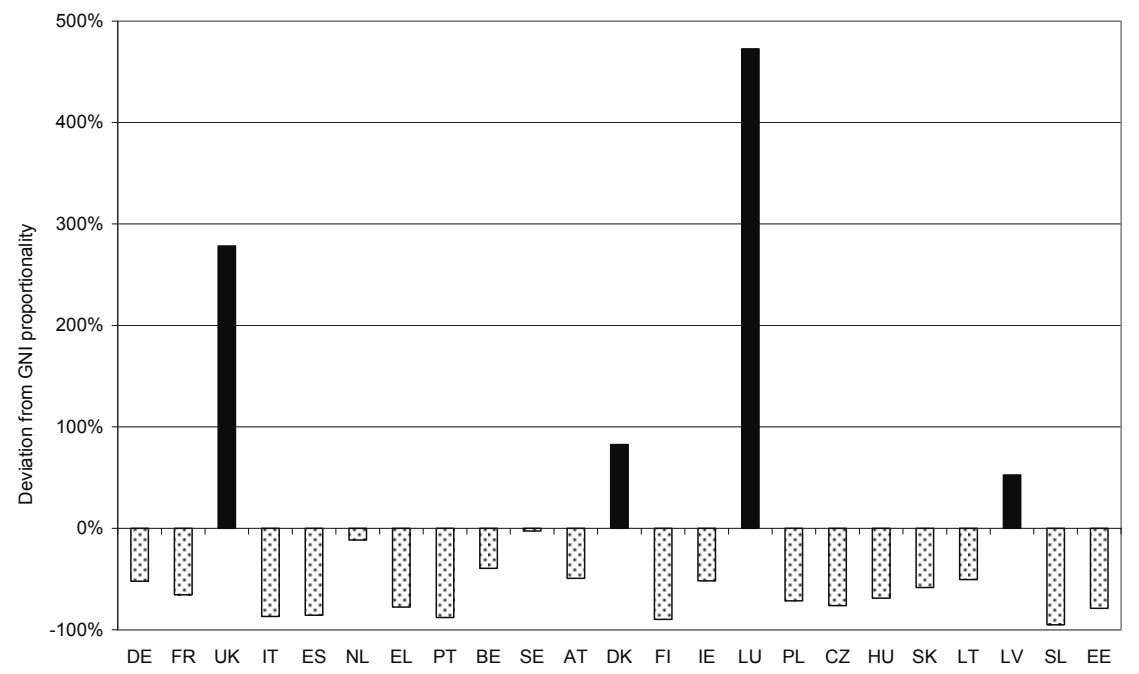

Source: Bank for International Settlement: Triennial Central Bank Survey of Foreign Exchange 2004, Basel, 2005; authors' calculations.

\section{Direct Taxes}

\section{a) Personal Income Tax}

The distributive consequences of a harmonised European personal income tax are much more difficult to estimate than those of the indirect taxes discussed above. They do not only depend on the distribution of the tax base among the member states but also on the design of the harmonised EU personal income tax, especially its progression. If a high degree of progressiveness is chosen, countries with a high inequality in its distribution of personal income will be burdened relatively more and vice versa.

A first indication that an EU personal income tax would also lead to a different distribution of national contributions to the EU budget than GNI proportionality can be derived from the national shares of compensation of employees and selfemployed persons. This was calculated via the national accounts data for the compensation of employees and adjusted by the estimated compensation of the 
self-employed according to the method of Musso and Westermann. ${ }^{64}$ The results for some member states are displayed in Figure 7.

Figure 7: Distributive Consequences of an EU Personal Income Tax

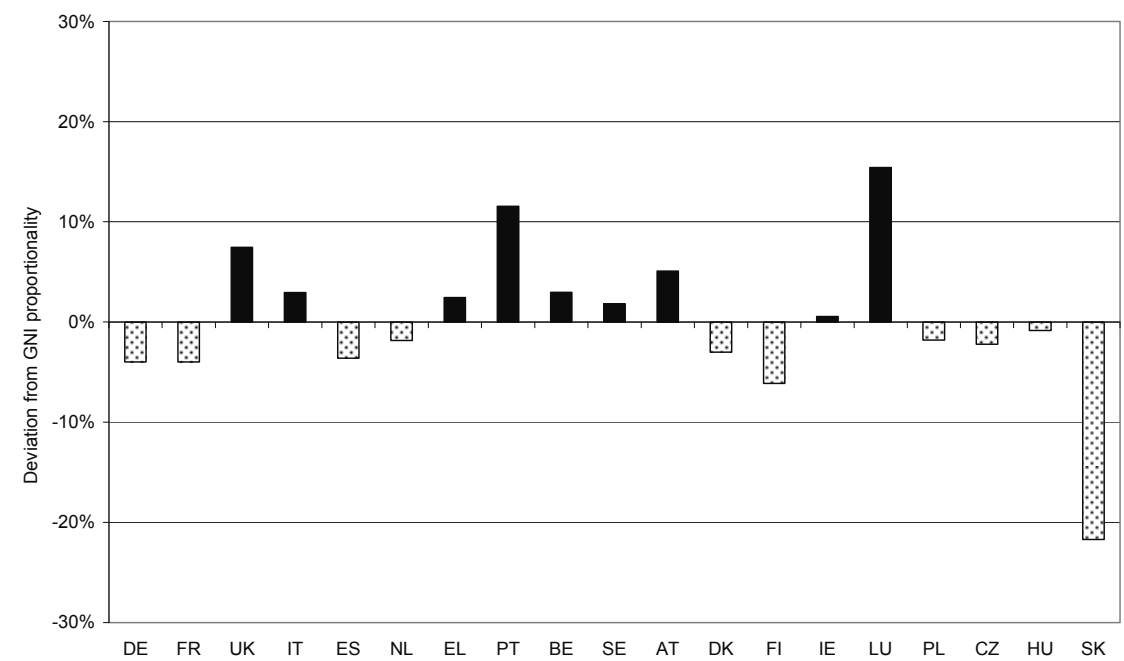

Source: Eurostat; authors' calculations.

Despite the fact that the overall compensation of employees is highly correlated with the national GNI, significant differences in its ratio can be observed for the European countries. Although this does not allow us to draw a final conclusion about the actual sharing of the burden of a personal income tax on the EU level, it helps to clarify that the diverging shares of labour income in the GNI of the member states would lead to a distribution pattern significantly different to GNI proportionality.

\section{b) Corporate Income Tax}

Generally, there might be good arguments in favour of harmonising corporate income tax bases in Europe. This section only evaluates the suitability of a corporate income tax as an EU tax. Similar to the personal income tax, the distribu- 
tive consequences of the introduction of an EU-wide harmonised corporate income tax are very difficult to estimate. Indicators for the hypothetical national tax burdens which are usually quoted, such as the share of income tax in GNI, are not very reliable as they are dominated by the impact of national differences in tax rates and bases. However, equivalent to the share of labour income in GNI, the share of corporate income can be assessed from national account data (Figure 8 ). The share of "gross operating surplus and mixed income" was reduced by the estimated share of compensation of those self-employed.

Figure 8: Distributive Consequences of an EU Corporate Income Tax

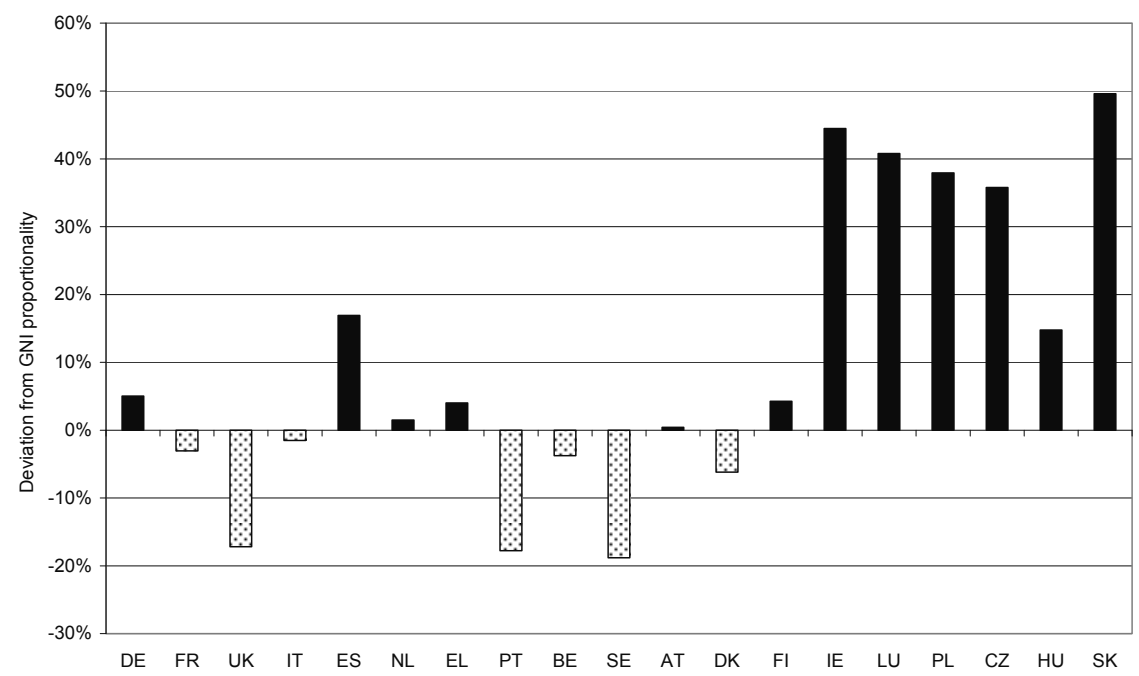

Source: Eurostat; authors' calculations.

It can be seen that, due to diverging shares of corporate income in GNI, the shares in tax base derived from national accounts would substantially differ from GNI proportionality. But in the case of corporate taxation, another problem for the assessment of the distributive effects caused by an EU tax arises from the fact that the actual tax payments are determined by the definition of the tax base which is not equal to the corporate profits as measured by national accounts statistics. This implies that the actual distribution of tax payments also depends on the design of a harmonised corporate income tax which would be a prerequisite for the use as an EU tax. For instance, the design of depreciation allowances 
might have a major impact due to national differences in industrial structure or form of organisation. Therefore, a conclusive assessment of the distributive effects of an EU tax based on a harmonised corporate tax is not feasible.

\section{Results}

Our analysis has shown that the distributive consequences of the considered taxes are very pronounced compared to the status quo. Table 1 summarises the effects from the perspective of the expected national support for the individual taxes; direct taxes were excluded due to the discussed difficulties of calculation and the unlikelihood of their introduction.

The Council votes of every country were assigned against the introduction of the respective tax, if the country would have to contribute more than $110 \%$ of the contributions under GNI-proportionality; they were assigned in favour of its introduction, if it would have to contribute less than $90 \%$ of its contributions under GNI-proportionality. A change within a margin of $10 \%$ was counted as indifference, as it may be assumed that countries which are confronted with a minor loss compared to the status quo may be compensated for their approval in other policy areas. Of course, one has to bear in mind that voting behaviour of a member state would not exclusively be based on the distributive advantages or disadvantages of a certain tax. In the past, countries indeed agreed on budgetary outcomes which provided them a worsening of their budgetary net balance, for instance in the context of package deals. However, recent empirical evidence on the negotiations on the Financial Perspective 2007-2013 shows that the actual coalitions which formed in the negotiation process in the Council can be explained very well by national interests quantified through partial net balances. ${ }^{65}$ This observation underlines the importance of the net balance when considering reforms of the system of own resources.

Table 1 shows that only the tax on foreign exchange transactions does not exceed the vetoing minority which is currently at $26 \%$. This means that no other proposal can be expected to find support in the Council under qualitative majority voting, even if we assume that the countries are ready to accept an increase of their contributions by $10 \%$.

65 Mrak, M./Rant, V.: Financial Perspective 2007-2013: Domination of National Interests, EU-Consent EU-Budget Working Paper no. 1, 2007. 
Table 1: Estimated Council Support for Selected EU Tax Proposals

\begin{tabular}{|l|c|c|c|c|c|}
\hline \multicolumn{1}{|c|}{ Tax } & $\begin{array}{c}\text { Council } \\
\text { votes pro }\end{array}$ & $\begin{array}{c}\text { Council } \\
\text { votes } \\
\text { against }\end{array}$ & Indifferent & $\begin{array}{c}\text { Biggest } \\
\text { winner }\end{array}$ & $\begin{array}{c}\text { Biggest } \\
\text { loser }\end{array}$ \\
\hline VAT & $24.0 \%$ & $36.1 \%$ & $39.9 \%$ & $\begin{array}{c}\text { Denmark } \\
(-18 \%)\end{array}$ & $\begin{array}{c}\text { Cyprus } \\
(+67 \%)\end{array}$ \\
\hline Tobacco & $41.8 \%$ & $46.0 \%$ & $12.2 \%$ & $\begin{array}{c}\text { Finland } \\
(-57 \%)\end{array}$ & $\begin{array}{c}\text { Bulgaria } \\
(+1298 \%)\end{array}$ \\
\hline Alcohol & $48.9 \%$ & $41.1 \%$ & $10.0 \%$ & $\begin{array}{c}\text { Sweden } \\
(-54 \%)\end{array}$ & $\begin{array}{c}\text { Latvia } \\
(+483 \%)\end{array}$ \\
\hline Fuel & $25.5 \%$ & $47.2 \%$ & $27.2 \%$ & $\begin{array}{c}\text { Denmark } \\
(-26 \%)\end{array}$ & $\begin{array}{c}\text { Luxembg. } \\
(+253 \%)\end{array}$ \\
\hline CO2 & $35.1 \%$ & $41.4 \%$ & $23.5 \%$ & $\begin{array}{c}\text { Sweden } \\
(-52 \%)\end{array}$ & $\begin{array}{c}\text { Bulgaria } \\
(+477 \%)\end{array}$ \\
\hline Kerosene & $60.3 \%$ & $35.1 \%$ & $4.6 \%$ & $\begin{array}{c}\text { Slovakia } \\
(-84 \%)\end{array}$ & $\begin{array}{c}\text { Cyprus } \\
(+424 \%)\end{array}$ \\
\hline $\begin{array}{l}\text { Foreign } \\
\text { Exchange } \\
\text { Transactions }\end{array}$ & $82.8 \%$ & $14.0 \%$ & $3.2 \%$ & $\begin{array}{l}\text { Slovenia } \\
(-95 \%)\end{array}$ & $\begin{array}{c}\text { Luxembg. } \\
(+473 \%)\end{array}$ \\
\hline
\end{tabular}

Source: Authors' calculations.

However, it has to be emphasised that any reform of the own resources system, including the introduction of an EU tax, would need a unanimous decision by the Council. Therefore it is necessary to look at the increase of the burden of the biggest loser of each tax option. These increases range from $67.1 \%$ for the VAT to more than $1900 \%$ for the tobacco tax. The introduction of a tax on foreign exchange transactions, albeit acceptable under majority voting, would also cause major increases of the contributions of Luxembourg and the United Kingdom, which would more than triple their contributions. Therefore it can be concluded that even if this tax is supported by the overwhelming majority of the national governments due to its distribution pattern, the veto of the countries which would bear the burden almost entirely would definitely avert its use as EU tax.

\section{Conclusion}

As discussed above, there are many doubts about the desirability and feasibility to replace the current system of own resources by an EU tax. In our view, most of the aims usually put forward by supporters of an EU tax are respectable but it 
is doubtful whether it would lead to significant improvements compared to the status quo. There are only few tax concepts which might enhance the visibility and simplicity of the system of own resources, aspects that are generally emphasised as main advantages of a tax-based system of own resources. We also do not agree that an EU tax would end political struggles due to the "juste retour" problem. Furthermore, an EU tax could be harmful, because it might trigger a loosening of budgetary discipline at the European and national levels, leading to an increasing fiscal burden on the citizens. Moreover, an EU tax would interfere with diverse national preferences regarding taxation and also with national federal structures. Additional costs would be caused by the need to harmonise national tax bases. Finally, there is no conclusive solution to the problem of instable revenues as an EU tax would either increase the danger of declining budgetary discipline if the EU was given the right to borrow or to increase the flexibility of spending or it would reverse any gain in visibility if further residual resources were added.

The positive analysis yields an even less favourable result for the prospects of an EU tax. First, several of the proposed alternatives are likely to fail since it cannot be presumed that the Council could agree on a common tax base. This mainly concerns taxes which are characterised by heterogeneous national preferences, especially personal and capital income taxes but also several excise duties. Second, what is even more important, the quantitative analyses have shown that none of these taxes have a distributive effect which comes at least close to that of the current system of own resources. Instead, it would cause arbitrary redistribution via the revenue side with significant divergence from GNI proportionality (winners and losers will depend on the type of tax which is chosen) and would even worsen today's situation in which single countries only feel discriminated due to imbalances on the expenditure side of the EU budget.

As a result, the introduction of any of the proposed taxes would make a number of countries worse off, and would therefore either provoke their veto or lead to an inflation of new abatements for disadvantaged countries. Even supporters of an EU tax agree that its redistributive effects would hardly be acceptable for all countries. ${ }^{66}$ Le Cacheux therefore proposes the introduction of a correction mechanism based on gross contributions in order to relieve countries with an excessive burden. ${ }^{67}$ Such a mechanism could be the capping of the tax base (as in 
the case of the VAT resources today), reduced rates of call for single countries, general correction mechanisms or exception rules on the revenue side. Regardless which mechanism would prevail, the main benefits that are mentioned by supporters of an EU tax, namely visibility and simplicity, would certainly be offset. 